\title{
Odpowiedzialność prawna nauczyciela
}

\author{
Legal Responsibility of the Teacher
}

Summary: The article presents definitions of basic concepts related to legal responsibility. The type of teacher's material liability, responsibility for maintaining order and discipline have been described in detail, and the scope of civil and criminal liability has been mentioned. Basic principles and conditions of liability as well as legal sanctions for committed violations have been indicated. The analysis was carried out on the basis of currently binding legal regulations.

Key words: teachers, educational law, legal responsibility, responsibility for maintaining discipline, material liability, responsibility for maintaining order

Zgodnie z definicją ze słownika języka polskiego pojęcie „odpowiedzialność” oznacza „obowiązek moralny lub prawny odpowiadania za swoje lub czyjeś czyny"1. O ile odpowiedzialność moralna zależy od wewnętrznych przekonań danej osoby, jej poglądów etycznych, religijnych czy filozoficznych, to odpowiedzialność prawna oznacza zastosowanie sankcji prawnej w sytuacji ujemnej oceny zachowania określonego podmiotu ${ }^{2}$. Zagadnienie odpowiedzialności prawnej ma zasadnicze znaczenie dla pracowników wszystkich zawodów, albowiem w związku z wykonywaniem obowiązków pracowniczych mogą w określonych przypadkach jej podlegać.

Niemniej jednak szczególnie istotna jest kwestia odpowiedzialności prawnej osób wykonujących jeden z najważniejszych zawodów zaufania publicznego, jakim jest zawód nauczyciela, który może być wykonywany przez osoby posia-

${ }^{1}$ Stownik języka polskiego PWN. https://sjp.pwn.pl/sjp/;2493511 [data dostępu: 3.01.2018].

2 S. Sykuna: Odpowiedzialność prawna. W: Leksykon wspótczesnej teorii i filozofii prawa. Red. J. Zajadło. Warszawa 2007, s. 215. 
dające odpowiednie wykształcenie, spełniające warunki zdrowotne niezbędne do wykonywania zawodu, a także przestrzegające podstawowych zasad moralnych $^{3}$. Zawód ten cieszy się dużym zaufaniem publicznym, a ponadto jest szczególnie chroniony na podstawie przepisów Ustawy z dnia 6 czerwca $1997 \mathrm{r}$. Kodeks karny ${ }^{4}$. Zgodnie z przepisami tego kodeksu nauczyciel, podczas pełnienia obowiązków służbowych lub w związku z nimi, korzysta z ochrony przewidzianej dla funkcjonariuszy publicznych ${ }^{5}$. Warto w tym miejscu zaznaczyć, że do podstawowych obowiązków nauczyciela należą: rzetelne realizowanie zadań związanych z powierzonym stanowiskiem, a także z funkcjami szkoły w zakresie dydaktyki, wychowania i opieki oraz zapewnienie uczniom bezpieczeństwa w czasie zajęć szkolnych. Zadaniem nauczyciela jest również wspieranie uczniów w ich rozwoju oraz kształcenie i wychowywanie w umiłowaniu Ojczyzny, w poszanowaniu Konstytucji Rzeczypospolitej Polskiej, w atmosferze wolności sumienia i szacunku dla każdego człowieka, a także dbałość o kształtowanie postaw moralnych i obywatelskich zgodnie z ideą demokracji, pokoju i przyjaźni między ludźmi różnych narodów, ras i światopoglądów. W ustawie akcentuje się także konieczność dążenia nauczyciela do pełnego własnego rozwoju osobowego ${ }^{6}$.

Nauczyciele ponoszą tożsamą odpowiedzialność prawną jak pracownicy innych zawodów, a więc co do zasady jest to odpowiedzialność wynikająca z ogólnych przepisów prawa. Wśród rodzajów odpowiedzialności wyróżnić można m.in.: materialną, porządkową, cywilną oraz karną. Wiele grup zawodowych objętych jest również szczególnym rodzajem odpowiedzialności o charakterze porządkowym, zwanej odpowiedzialnością dyscyplinarną, której dotyczą przepisy szczególne o randze ustawy, czyli tzw. pragmatyki służbowe?. W przypadku nauczycieli rodzaj odpowiedzialności dyscyplinarnej ujęty jest w rozdziale dziesiątym Ustawy z dnia 26 stycznia 1982 r. Karta Nauczyciela oraz w rozdziale czwartym Ustawy z dnia 27 lipca 2005 r. Prawo o szkolnictwie wyższym ${ }^{8}$, w zakresie dotyczącym nauczycieli akademickich.

Odpowiedzialność materialna nauczycieli wynika wprost ze stosunku pracy łączącego ich z pracodawcą i jest szczegółowo uregulowana $\mathrm{w}$ dziale piątym „Odpowiedzialność materialna pracowników” Ustawy z dnia 26 czerwca $1974 \mathrm{r}$. Kodeks pracy ${ }^{9}$. Wyróżnia się w niej odpowiedzialność pracownika za szkodę wyrządzoną pracodawcy z winy umyślnej i nieumyślnej, uregulowaną w art. 114-

${ }^{3}$ Art. 9 ust. 1 Ustawy z dnia 26 stycznia 1982 r. - Karta nauczyciela. Dz.U. 1982, nr 3, poz. 19 z późn. zm. - dalej jako: Karta nauczyciela.

${ }^{4}$ Dz.U. 1997, nr 88, poz. 553 z późn. zm. — dalej jako: Kodeks karny.

${ }^{5}$ Art. 63 ust. 1 Karty nauczyciela.

${ }^{6}$ Art. 6 Karty nauczyciela.

7 E. Staszewska: Odpowiedzialność pracownicza. Warszawa 2013, s. 177.

${ }^{8}$ Dz.U. 2005, nr 164, poz. 1365 z późn. zm. — dalej jako: Prawo o szkolnictwie wyższym.

9 Dz.U. 1974, nr 24, poz. 141 z późn. zm. — dalej jako: Kodeks pracy. 
123, oraz odpowiedzialność za mienie powierzone pracownikowi, co ujęte jest w art. 124-127. Nauczyciel ponosi odpowiedzialność materialną na zasadach ogólnych, jeśli wskutek niewykonania lub nienależytego wykonania obowiązków pracowniczych ze swej winy wyrządził pracodawcy szkodę (majątkową lub niemajątkową) ${ }^{10}$. Aby nauczyciel mógł zostać pociągnięty do odpowiedzialności materialnej ogólnej, muszą zostać spełnione łącznie następujące przesłanki: wyrządzenie szkody pracodawcy mającej bezpośredni związek przyczynowy związany z bezprawnym działaniem lub zaniechaniem pracownika wskutek niewykonania lub nienależytego wykonania obowiązków pracowniczych, która to szkoda nastąpiła $\mathrm{z}$ winy nauczyciela ${ }^{11}$. Obowiązkiem pracodawcy jest udowodnienie naruszenia powyższych przesłanek przez nauczyciela. Nieudowodnienie jednego $\mathrm{z}$ tych elementów skutkuje brakiem możliwości pociągnięcia nauczyciela do odpowiedzialności materialnej. Należy także zaznaczyć, że nauczyciel może ponieść odpowiedzialność za szkodę w granicach rzeczywistej straty poniesionej przez pracodawcę i to właśnie pracodawca zobowiązany jest do wskazania wysokości powstałej szkody. W sytuacji, gdy szkoda została wyrządzona przez nauczyciela nieumyślnie, to wysokość odszkodowania nie może przekroczyć kwoty trzymiesięcznego wynagrodzenia pracownika, jeśli zaś szkoda została wyrządzona umyślnie, to obowiązkiem nauczyciela jest jej naprawienie w całości ${ }^{12}$. Jeśli szkoda została wyrządzona osobie trzeciej (np. uczniowi), wtedy zobowiązanym do jej naprawienia jest pracodawca, który następnie może żądać od pracownika zwrotu poniesionych kosztów ${ }^{13}$. Nauczyciel nie ponosi odpowiedzialności za szkodę w części, w jakiej pracodawca lub inne osoby przyczyniły się do jej powstania lub zwiększenia.

Trzeba nadmienić, że nauczyciel nie jest obciążony ryzykiem związanym z działalnością pracodawcy. Jeśli więc, przykładowo, zajęcia lekcyjne z jakichś powodów zostaną odwołane, nauczyciel zachowuje prawo do wynagrodzenia za ten okres. Ponadto nauczyciel nie odpowiada za szkodę wynikłą w związku $\mathrm{z}$ działaniem $\mathrm{w}$ granicach dopuszczalnego ryzyka ${ }^{14}$, czyli chociażby w sytuacji, kiedy działając $\mathrm{w}$ interesie zakładu pracy, poświęca dobro mniejszej wartości w celu zapobieżenia powstania szkody znacznie większej wartości ${ }^{15}$. Jeżeli szkodę wyrządziło kilku nauczycieli, to każdy z nich ponosi odpowiedzialność za część szkody, która ustalana jest w oparciu o zakres przyczynienia się i stopień winy danej osoby ${ }^{16}$.

\footnotetext{
${ }^{10}$ Art. 114 Kodeksu pracy.

${ }^{11}$ E. Staszewska: Odpowiedzialność pracownicza..., s. 27-28.

${ }^{12}$ Art. 119 w zw. z art. 122 Kodeksu pracy.

${ }_{13}$ Art. 120 Kodeksu pracy.

${ }_{14}$ Art. 117 Kodeksu pracy.

${ }_{15}$ Zob. Wyrok Sadu Najwyższego z dnia 8 października 1981 r. w sprawie o sygn. akt IV PR 301/81, OSNC 1982/2-3/43.

${ }^{16}$ Art. 118 Kodeksu pracy.
} 
Jak już powyżej wskazano, pracodawca może powierzyć nauczycielowi z obowiązkiem zwrotu albo do wyliczenia się określone mienie, jak chociażby pieniądze, papiery wartościowe lub kosztowności, a także narzędzia i instrumenty bądź podobne przedmioty, a ponadto środki ochrony indywidualnej oraz odzież i obuwie robocze. Za szkodę powstałą w powierzonym mieniu nauczyciel odpowiada w pełnej wysokości, bez jakichkolwiek ograniczeń ${ }^{17}$. Pociągnięcie nauczyciela do odpowiedzialności jest możliwe w przypadku prawidłowego powierzenia mienia - czyli po wyrażeniu przez nauczyciela zgody na powierzenie mienia z obowiązkiem zwrotu lub wyliczenia się, z jednoczesnym umożliwieniem sprawdzenia stanu ilościowego i jakościowego mienia oraz faktycznego objęcia go w posiadanie, celem sprawowania nad nim pieczy. Niezbędne jest także wykazanie przez pracodawcę szkody w powierzonym mieniu i określenie jej wysokości ${ }^{18}$. Nauczyciel może uwolnić się od tego rodzaju odpowiedzialności, jeśli wykaże, że szkoda powstała z przyczyn od niego niezależnych bądź wskutek niezapewnienia przez pracodawcę warunków umożliwiających zabezpieczenie powierzonego mienia ${ }^{19}$. Na podstawie pisemnej umowy o współodpowiedzialności materialnej możliwe jest również powierzenie przez pracodawcę mienia wspólnie kilku nauczycielom, którzy w przypadku powstania szkody odpowiadają wspólnie w częściach określonych w zawartej umowie, przy czym za całość szkody lub za określoną jej część odpowiedzą tylko ci pracownicy, którzy są jej bezpośrednimi sprawcami ${ }^{20}$.

Z kolei o zasadach odpowiedzialności porządkowej nauczycieli mówi art. 75 ust. 2 Ustawy Karta Nauczyciela, odsyłając w zakresie uchybień przeciwko porządkowi pracy (ujętych w art. 108 Kodeksu pracy) do wymiaru kar porządkowych zawartych w Kodeksie pracy, czyli kary upomnienia, kary nagany lub kary pieniężnej ${ }^{21}$. Pierwsze dwie sankcje pracodawca może zastosować w przypadku nieprzestrzegania przez nauczycieli ustalonej organizacji i porządku w procesie pracy, przepisów bezpieczeństwa i higieny pracy, przepisów przeciwpożarowych oraz przyjętego sposobu potwierdzania przybycia i obecności w pracy, a także usprawiedliwiania nieobecności w pracy. Jeśli zaś chodzi o ostatnią $\mathrm{z}$ wymienionych kar — karę pieniężną — to może ona zostać nałożona w sytuacji nieprzestrzegania przepisów bezpieczeństwa i higieny pracy lub przepisów przeciwpożarowych, a także w przypadku opuszczenia pracy bez usprawiedliwienia lub stawienia się do pracy w stanie nietrzeźwości bądź spożywania alkoholu w czasie pracy. Kara pieniężna zarówno za jedno przekroczenie, jak i za każdy dzień nieusprawiedliwionej nieobecności nie może przewyższać jed-

${ }^{17}$ Art. $124 \S 1$ Kodeksu pracy.

18 Zob. Wyrok Sąu Najwyższego z dnia 25 września 1985 r. w sprawie o sygn. akt IV PR 200/85, OSNC 1986/5/84.

${ }_{19}$ Art. $124 \S 3$ Kodeksu pracy.

20 Art. 125 Kodeksu pracy.

${ }^{21}$ Art. 75 ust. 2 Kodeksu pracy. 
nodniowego wynagrodzenia pracownika ${ }^{22}$. Pracodawca może zastosować karę porządkową w terminie do dwóch tygodni od uzyskania wiadomości o naruszeniu obowiązków przez nauczyciela, jednakże nie później niż po upływie trzech miesięcy od zdarzenia. W przypadku nieobecności pracownika bieg pierwszego $\mathrm{z}$ terminów ulega zawieszeniu do momentu stawienia się w pracy. Dodatkowo sama kara może być zastosowana wyłącznie po wysłuchaniu pracownika, co — dla celów dowodowych — powinno zostać potwierdzone notatką służbową ${ }^{23}$. Przy wymierzaniu kary pracodawca winien rozważyć posiadane informacje o rodzaju naruszenia obowiązków pracowniczych, stopniu winy oraz dotychczasowym przebiegu pracy pracownika ${ }^{24}$. Ustawa nakłada na pracodawcę również obowiązek pisemnego poinformowania nauczyciela o nałożonej karze $\mathrm{z}$ jednoczesnym wskazaniem daty oraz rodzaju naruszenia obowiązków pracowniczych wraz z pouczeniem o prawie zgłoszenia sprzeciwu i terminie jego wniesienia, który wynosi siedem dni ${ }^{25}$.

Nauczyciel może wnieść sprzeciw w przypadku, gdy kara została wymierzona z naruszeniem przepisów prawa. W tym zakresie możliwe jest wskazanie zarzutu naruszenia zarówno przepisów prawa materialnego, jak i procedury nakładania kar porządkowych. O uwzględnieniu lub odrzuceniu sprzeciwu decyduje pracodawca po zapoznaniu się ze stanowiskiem zakładowej organizacji związkowej reprezentującej nauczyciela. Brak reakcji pracodawcy na sprzeciw $\mathrm{w}$ terminie czternastu dni od dnia jego wniesienia jest równoznaczny z jego uwzględnieniem. Natomiast w przypadku odrzucenia sprzeciwu przez pracodawcę, nauczycielowi w ciągu czternastu dni przysługuje prawo złożenia wniosku do sądu pracy o uchylenie zastosowanej wobec niego kary ${ }^{26}$. Zatarcie kary porządkowej, czyli uznanie jej za niebyłą, następuje z mocy prawa w razie uwzględnienia sprzeciwu przez pracodawcę uchylenia kary porządkowej przez sąd pracy, po roku nienagannej pracy. Fakultatywnie pracodawca, z własnej inicjatywy lub na wniosek zakładowej organizacji związkowej reprezentującej pracownika, może uznać karę za niebyłą przed upływem roku ${ }^{27}$. Należy również zwrócić uwagę, że nauczyciel za jedno naruszenie porządku pracy może zostać ukarany tylko jedną karą porządkową, tym samym nie jest możliwe jednoczesne nałożenie kary porządkowej pieniężnej i niepieniężneje ${ }^{28}$.

Zasady odpowiedzialności porządkowej mają pełnić zarówno funkcję prewencyjno-wychowawczą - a więc mobilizować nauczycieli do przestrzegania ustalonego porządku i dyscypliny pracy oraz przestrzegać przed konsek-

\footnotetext{
22 Art. 108 Kodeksu pracy.

23 Art. 109 Kodeksu pracy.

${ }^{24}$ Art. 111 Kodeksu pracy.

25 Art. 110 Kodeksu pracy.

${ }^{26}$ Art. 112 Kodeksu pracy.

27 Art. 113 Kodeksu pracy.

${ }^{28}$ E. Staszewska: Odpowiedzialność pracownicza..., s. 175.
} 
wencjami niedopełnienia obowiązków pracowniczych — jak i funkcję represyjną, polegającą na ukaraniu pracownika za naruszenie obowiązków ${ }^{29}$.

Odpowiedzialność dyscyplinarna nauczycieli jest odpowiedzialnością na zasadzie winy za postępowanie uchybiające godności zawodu nauczyciela ${ }^{30}$ lub powierzonym obowiązkom ${ }^{31}$. Od 2009 roku ten rodzaj odpowiedzialności obejmuje wszystkich nauczycieli, bez względu na posiadany stopień awansu zawodowego, co ma na celu mobilizować nauczycieli do postępowania zgodnego z normami etycznymi oraz zwiększać zaufanie społeczeństwa do tego zawodu. Pierwszym etapem postępowania dyscyplinarnego jest przeprowadzenie postępowania wyjaśniającego, które wszczynane jest przez rzecznika dyscyplinarnego na polecenie organu, który go powołał (wojewoda, właściwy minister). Jego celem jest wyjaśnienie okoliczności koniecznych do ustalenia znamion przewinienia dyscyplinarnego; przedstawienie obwinionemu nauczycielowi zarzutów, jak również odebranie od niego wyjaśnień; zapoznanie się z zebranymi dowodami oraz rozpatrzenie ewentualnych wniosków ${ }^{32}$. Po przeprowadzeniu postępowania wyjaśniającego rzecznik może zdecydować o skierowaniu wniosku o wszczęcie postępowania dyscyplinarnego do komisji dyscyplinarnej albo o wydaniu postanowienia o umorzeniu postępowania, na które w terminie siedmiu dni od dnia doręczenia przysługuje zażalenie do komisji dyscyplinarnej33.

Po skierowaniu przez rzecznika wniosku o wszczęcie postępowania dyscyplinarnego następnym etapem jest przeprowadzenie postępowania rozpoznawczego przez właściwą komisję dyscyplinarną przy wojewodzie. Komisje dyscyplinarne powoływane są na czteroletnią kadencję i są niezawisłe w zakresie orzekania $^{34}$. Istotą pracy komisji jest przeprowadzenie postępowania dowodowego oraz wszechstronne wyjaśnienie sprawy, a następnie wydanie orzeczenia o ukaraniu lub uniewinnieniu nauczyciela, względnie umorzeniu postępowania dyscyplinarnego.

29 J. Rudnik: Odpowiedzialność cywilno-prawna i zadania nauczycieli zwiazane z bezpieczeństwem uczniów. http://www.oskko.edu.pl/wroclaw2013/materialy/odpowiedzialnosc_praw na_nauczycieli.pdf [data dostępu: 3.01.2018].

${ }^{30}$ Pojęcie godności zawodu nauczyciela nie ma legalnej definicji, jednakże zgodnie ze stanowiskiem Ministerstwa Edukacji Narodowej z dnia 9 maja 2017 r. (11846/2017, LEX nr 351099) za uchybienia godności zawodu nauczyciela powinny zostać uznane zachowania odbierane negatywnie przez otoczenie danego nauczyciela (dyrektora szkoły, innych nauczycieli, rodziców), będą więc to wszelkie działania, które w sposób ewidentny naruszają ogólne normy etyczne i normy zachowania przyjęte w środowisku szkolnym (oświatowym).

${ }^{31}$ Art. 75 ust. 1 Karty nauczyciela.

${ }^{32}$ T. Kuczyński: Odpowiedzialność porzadkowa i dyscyplinarna. W: System prawa administracyjnego. T. 11. Red. R. Hauser, Z. Niewiadomski, A. Wróbel. Warszawa 2011, s. 454455.

${ }^{33}$ Art. 85 Karty nauczyciela.

${ }^{34}$ Art. 77 ust. 5 w zw. z art. 85 a Karty nauczyciela. 
W przypadku ukarania obwiniony nauczyciel zostaje uznany winnym w całości lub w części zarzucanego mu czynu i wymierza się mu karę dyscyplinarną, biorąc pod uwagę okoliczności zarzucanego czynu, stopień winy, szkodliwość społeczną czynu, a także zachowanie się nauczyciela przed popełnieniem czynu i po nim. Kary dyscyplinarne występują w postaci: nagany z ostrzeżeniem; zwolnienia $\mathrm{z}$ pracy $\mathrm{w}$ danej szkole; zwolnienia $\mathrm{z}$ pracy $\mathrm{z}$ zakazem przyjmowania ukaranego do pracy w zawodzie nauczyciela w okresie trzech lat od ukarania, a nawet całkowitego wydalenia $\mathrm{z}$ zawodu ${ }^{35}$. $\mathrm{Z}$ kolei uniewinnienie nauczyciela następuje w sytuacji, jeśli postępowanie dyscyplinarne nie potwierdziło popełnienia przez nauczyciela zarzucanego mu czynu bądź też zarzucany mu czyn nie zawiera znamion uchybienia godności zawodu nauczyciela lub jego obowiązkom. Natomiast umorzenie postępowania dyscyplinarnego jest możliwe m.in. jeśli nauczyciel został już za ten czyn ukarany karą porządkową, jeśli zmarł bądź nastąpiło przedawnienie odpowiedzialności dyscyplinarnej ${ }^{36}$. Wobec tego, że postępowanie dyscyplinarne jest dwuinstancyjne, kolejnym jego etapem - w przypadku wniesienia odwołania w terminie czternastu dni od dnia doręczenia orzeczenia przez rzecznika dyscyplinarnego lub obwinionego nauczyciela - jest postępowanie odwoławcze, które toczy się przed odwoławczą komisją dyscyplinarną przy ministrze właściwym do spraw oświaty i wychowania lub odwoławczą komisją dyscyplinarną przy ministrze właściwym do spraw kultury i ochrony dziedzictwa narodowego ${ }^{37}$. Po przeprowadzeniu rozprawy komisja może zaskarżone orzeczenie utrzymać w mocy lub uchylić je w całości bądź w części, tudzież uchylić je z jednoczesnym przekazaniem sprawy do ponownego rozpoznania przez komisję dyscyplinarną pierwszej instancji ${ }^{38}$. Również od prawomocnego orzeczenia odwoławczej komisji dyscyplinarnej obwinionemu nauczycielowi oraz rzecznikowi dyscyplinarnemu przysługuje odwołanie do właściwego miejscowo sądu apelacyjnego: sądu pracy i ubezpieczeń społecznych, w terminie czternastu dni od dnia doręczenia orzeczenia z uzasadnieniem. Orzeczenie sądu apelacyjnego jest ostateczne i nie przysługuje od niego skarga kasacyjna ${ }^{39}$. Ustawa przewiduje, że co do zasady postępowanie dyscyplinarne może być wszczęte przed upływem trzech miesięcy od dnia powzięcia wiadomości o popełnieniu czynu uchybiającego godności zawodu nauczyciela bądź jego obowiązkom lub do trzech lat od popełnienia takiego czynu ${ }^{40}$. Kara nagany z ostrzeżeniem oraz kara zwolnienia z pracy ulegają zatarciu po upływie trzech lat od dnia doręczenia prawomocnego orzeczenia, z kolei kara zwolnienia z pracy z zakazem przyjmowania ukaranego do pracy

\footnotetext{
35 Art. 76 ust. 1 i 2 Karty nauczyciela.

36 Art. 85 j Karty nauczyciela.

37 Art. 77 Karty nauczyciela.

38 Art. 851 Karty nauczyciela.

39 Art. 85 m Karty nauczyciela.

${ }^{40}$ Art. 85 o Karty nauczyciela.
} 
w zawodzie nauczyciela $\mathrm{w}$ okresie trzech lat ulega zatarciu dopiero po upływie sześciu lat ${ }^{41}$.

Podobnej odpowiedzialności dyscyplinarnej jak nauczyciele podlegają również nauczyciele akademiccy. Różnice polegają m.in. na sposobie powoływania rzeczników dyscyplinarnych, których spośród nauczycieli akademickich powołuje częściowo rektor, a częściowo minister właściwy do spraw szkolnictwa wyższego ${ }^{42}$. Co istotne, rzecznicy dyscyplinarni mogą wszcząć postępowanie wyjaśniające zarówno na wniosek organu, przez który zostali powołani, jak i z urzędu. Ustawowym terminem na wszczęcie postępowania wyjaśniającego są trzy miesiące od pozyskania informacji o popełnieniu czynu skutkującego możliwością poniesienia odpowiedzialności, przy czym takie postępowanie wyjaśniające nie może być wszczęte po upływie pięciu lat od popełnienia czynu, chyba że czyn zawiera znamiona przestępstwa — wtedy termin ten jest równy upływowi okresu przedawnienia przewidzianego dla tego przestępstwa $^{43}$.

Postępowanie dyscyplinarne nauczycieli akademickich również jest dwuinstancyjne, jednakże karę upomnienia za przewinienia dyscyplinarne wagi mniejszej może nałożyć rektor uczelni, po wysłuchaniu nauczyciela. Samo postępowanie w pierwszej instancji toczy się przed uczelnianą komisją dyscyplinarną do spraw nauczycieli akademickich, w drugiej zaś — przed komisją dyscyplinarną do spraw nauczycieli akademickich przy Radzie ${ }^{44}$. Uprawnieniem stron postępowania jest prawo odwołania do Sądu Apelacyjnego w Warszawie Sądu Pracy i Ubezpieczeń Społecznych od prawomocnego orzeczenia komisji dyscyplinarnej drugiej instancji. Z kolei za orzeczenie wydane przez sąd nie służy skarga kasacyjna ${ }^{45}$. Zupełnie inny jest katalog kar dyscyplinarnych w szkolnictwie wyższym i obejmuje on: upomnienie, naganę, jak również naganę z pozbawieniem prawa do pełnienia funkcji kierowniczych w uczelniach na okres od trzech miesięcy do pięciu lat, a także pozbawienie prawa do wykonywania zawodu nauczyciela akademickiego na okres od pięciu miesięcy do pięciu lat lub na stałe ${ }^{46}$. Zatarcie kary upomnienia i nagany następuje po upływie trzech lat, a pozostałych kar dyscyplinarnych (z wyłączeniem kary orzeczonej na stałe) dopiero po pięciu latach od dnia doręczenia nauczycielowi akademickiemu prawomocnego orzeczenia o ukaraniu ${ }^{47}$.

Oczywiście nauczyciele jako pracownicy mogą w związku z pełnionymi obowiązkami podlegać również odpowiedzialności cywilnej, która ujęta jest

\footnotetext{
${ }^{41}$ Art. 85 s Karty nauczyciela.

42 Art. 145 Prawa o szkolnictwie wyższym.

43 Art. 144 Prawa o szkolnictwie wyższym.

44 Art. 142 Prawa o szkolnictwie wyższym.

45 Art. 146 ust. 4 Prawa o szkolnictwie wyższym.

46 Art. 140 Prawa o szkolnictwie wyższym.

47 Art. 144 ust. 6 Prawa o szkolnictwie wyższym.
} 
w Ustawie z dnia 23 kwietnia 1964 r. Kodeks cywilny ${ }^{48}$. Rozróżnia się odpowiedzialność cywilną kontraktową, dotyczącą wyrządzenia szkody przez niewykonanie lub nienależyte wykonanie zobowiązania ${ }^{49}$, a także odpowiedzialność cywilną deliktową, związaną z wyrządzeniem szkody czynem niedozwolonym ${ }^{50}$. Podstawę odpowiedzialności cywilnej nauczyciela stanowi zasada winy oraz zasada ryzyka. Pierwsza z nich polega na tym, że ponosi on odpowiedzialność, jeśli można mu przypisać winę. $Z$ kolei w przypadku odpowiedzialności na zasadzie ryzyka nauczyciel odpowiada za sam fakt wyrządzenia szkody, niezależnie od swojej winy. Są to sytuacje, w których osoba odpowiada za wywołanie szkody przez pewne zdarzenie, które musi być ściśle wskazane $\mathrm{w}$ przepisie, jak chociażby np. odpowiedzialność za osoby pomagające w wykonaniu zobowiązania, odpowiedzialność zwierzchnika za podwładnego, odpowiedzialność posiadacza budowli za jej zawalenie się, odpowiedzialność osób prowadzących przedsiębiorstwo ${ }^{51}$. Wskazać należy, że o odpowiedzialności cywilnej można mówić dopiero po powstaniu uszczerbku majątkowego lub niemajątkowego w wyniku ludzkiego działania, niewykonania lub nienależytego wykonania zobowiązania bądź innego zdarzenia, z którym ustawa łączy obowiązek odszkodowawczy. Ponadto między zdarzeniem a zaistniałą w jego wyniku szkodą musi istnieć związek przyczynowy ${ }^{52}$. Sankcje z tytułu odpowiedzialności cywilnej mają charakter majątkowy i polegają m.in. na zapłacie odszkodowania.

Nauczyciele mogą także podlegać odpowiedzialności karnej, co ma miejsce w sytuacji popełnienia czynu, który jest przestępstwem lub wykroczeniem. Ustawa z dnia 6 czerwca 1997 r. Kodeks karny wskazuje, że odpowiedzialności karnej podlega ten, kto popełnia czyn zabroniony pod groźbą kary przez ustawę obowiązującą $\mathrm{w}$ czasie jego popełnienia ${ }^{53}$. Z kolei Ustawa z dnia 20 maja 1971 r. Kodeks wykroczeń stwierdza, że odpowiedzialności za wykroczenie podlega ten tylko, kto popełnia czyn społecznie szkodliwy, zabroniony przez ustawę obowiązującą w czasie jego popełnienia pod groźbą kary aresztu,

${ }^{48}$ Dz.U. 1964, nr 16, poz. 93 - dalej jako: Kodeks cywilny.

49 Art. 471 Kodeksu cywilnego — odpowiedzialność kontraktowa zachodzi w razie niewykonania lub nienależytego wykonania zobowiązania, albowiem w przypadku gdy zobowiązanie jest wykonane zgodnie z jego treścią, to dochodzi do zaspokojenia interesu wierzyciela i wygaśnięcia zobowiązania. $\mathrm{Z}$ odpowiedzialnością tego rodzaju wiąże się obowiązek naprawienia powstałej szkody.

${ }^{50}$ Art. 415 Kodeksu cywilnego — odpowiedzialność deliktowa wiąże się z ogólną formułą odpowiedzialności za czyn zawiniony i wyrządzoną w ten sposób drugiemu szkodą. Ten rodzaj odpowiedzialności może być przypisany także za niezawinione zachowania, a nawet wówczas, gdy szkoda została wyrządzona niebezpośrednio w związku z działaniem człowieka.

${ }^{51}$ Art. 433-436, 474 Kodeksu cywilnego.

${ }^{52}$ Odpowiedzialność cywilna nauczycieli - zasady ogólne. http://www.oswiata.abc.com.pl/ czytaj/-/artykul/odpowiedzialnosc-cywilna-nauczycieli-zasady-ogolne [data dostępu: 3.01.2018].

${ }_{53}$ Art. 1 Kodeksu karnego. 
ograniczenia wolności, grzywny do 5000 zł lub nagany ${ }^{54}$. W obu przypadkach odpowiedzialności nie podlega sprawca czynu zabronionego, jeżeli nie można mu przypisać winy w czasie czynu. Czyn zabroniony może być popełniony umyślnie (zamiar bezpośredni lub ewentualny) lub nieumyślnie (lekkomyślność lub niedbalstwo) ${ }^{55}$. Odpowiedzialność karną stosuje się za dokonanie przestępstwa i za usiłowanie dokonania go $^{56}$, a także za przygotowanie ${ }^{57}-\mathrm{w}$ sytuacji gdy ustawa tak stanowi. Odpowiedzialność karną ponoszą nie tylko sprawcy (współsprawcy) przestępstwa, ale również podżegacz (nakłaniający) i pomocnik (ułatwiający). Dodać również należy, że odpowiedzialność karną wyłącza: obrona konieczna, stan wyższej konieczności, działanie w ramach uprawnień lub obowiązków, zgoda dysponenta dobrem, czynności lecznicze, dozwolone ryzyko nowatorstwa, np. eksperyment medyczny, techniczny, ekonomiczny, uprawianie sportu oraz niepoczytalność, błąd co do faktu, nieświadomość bezprawności czynu i rozkaz przełożonego ${ }^{58}$. Karami za przestępstwa są: grzywna, ograniczenie wolności, pozbawienie wolności, dwadzieścia pięć lat pozbawienia wolności, dożywotnie pozbawienie wolności; natomiast za wykroczenia: areszt, ograniczenie wolności, grzywna i nagana. W przypadku prawomocnego skazania za umyślne przestępstwo stosunek pracy nauczyciela wygasa z mocy prawa $^{59}$.

Reasumując, nauczyciele, w związku z pełnionymi obowiązkami, podlegają odpowiedzialności na tożsamych zasadach jak przedstawiciele innych zawodów. W sposób szczególny została uregulowana jedynie odpowiedzialność dyscyplinarna nauczycieli i nauczycieli akademickich. Oczywiście specyfika zawodu nauczyciela, polegająca na ciągłym kontakcie z dziećmi i młodzieżą, wiąże się z zachowaniem wzmożonej uwagi, uczniowie wymagają bowiem nieustannej kontroli i podlegają ciągłemu nadzorowi. Sam zakres obowiązków

${ }^{54}$ Art. 1 Ustawy z dnia 20 maja 1971 r. Kodeks wykroczeń. Dz.U. 1971, nr 12, poz. 114 z późn. zm. - dalej jako: Kodeks wykroczeń.

${ }_{55}$ Zob. art. 9 Kodeksu karnego, który mówi, że czyn zabroniony popełniony jest umyślnie, jeżeli sprawca ma zamiar jego popełnienia, to jest chce go popełnić albo przewidując możliwość jego popełnienia, na to się godzi; natomiast nieumyślnie — w sytuacji gdy sprawca, nie mając zamiaru jego popełnienia, popełnia go jednak na skutek niezachowania ostrożności wymaganej w danych okolicznościach, mimo że możliwość popełnienia tego czynu przewidywał albo mógł przewidzieć.

${ }_{56}$ Zob. art. 13 Kodeksu karnego, który wskazuje, że odpowiada za usiłowanie, kto w zamiarze popełnienia czynu zabronionego swoim zachowaniem bezpośrednio zmierza do jego dokonania, które jednak nie następuje.

${ }_{57}$ Zob. art. 16 Kodeksu karnego, określający, że przygotowanie zachodzi tylko wtedy, gdy sprawca w celu popełnienia czynu zabronionego podejmuje czynności mające stworzyć warunki do przedsięwzięcia czynu zmierzającego bezpośrednio do jego dokonania, w szczególności w tymże celu wchodzi w porozumienie z inną osobą, uzyskuje lub przysposabia środki, zbiera informacje lub sporządza plan działania.

${ }_{58}$ Art. 25-31 Kodeksu karnego.

${ }_{59}$ Art. 26 ust. 1 pkt 3 Karty nauczyciela. 
nauczycieli wskazuje, że mogą oni naruszyć zdecydowanie więcej przepisów i norm aniżeli pracownicy innych zawodów. Obowiązki nauczycieli wykonywane w sposób nieodpowiedni mogą być źródłem odpowiedzialności prawnej na wielu płaszczyznach (rodzajach). Nie sposób wskazać przykładów naruszeń przepisów przez tę grupę zawodową, gdyż każdy przypadek jest zawsze odrębnie kwalifikowany i oceniany. Nie ulega jednak wątpliwości, że choćby z uwagi na wysoki stopień społecznego zaufania do tego zawodu, każdy rodzaj naruszenia powinien być szczególnie piętnowany.

Analiza wybranych aspektów odpowiedzialności prawnej dowodzi, że zawód nauczyciela wiąże się z dużą odpowiedzialnością nie tylko społeczną, ale również prawną, a do jego wykonywania niezbędne jest spełnianie odpowiednich wymagań nie tylko formalnych, ale przede wszystkim etycznych.

\section{Bibliografia}

Kuczyński T.: Odpowiedzialność porządkowa i dyscyplinarna. W: System prawa administracyjnego. T. 11. Red. R. Hauser, Z. Niewiadomski, A. Wróbel. Warszawa 2011.

Staszewska E.: Odpowiedzialność pracownicza. Warszawa 2013.

Sykuna S.: Odpowiedzialność prawna. W: Leksykon wspótczesnej teorii i filozofii prawa. Red. J. Zajadło. Warszawa 2007.

Ustawa z dnia 20 maja 1971 r. - Kodeks wykroczeń. Dz.U. 1971, nr 12, poz. 114 z późn. zm. Ustawa z dnia 23 kwietnia 1964 r. - Kodeks cywilny. Dz.U. 1964, nr 16, poz. 93 z późn. zm.

Ustawa z dnia 26 czerwca 1974 r. - Kodeks pracy. Dz.U. 1974, nr 24, poz. 141 z późn. zm.

Ustawa z dnia 26 stycznia 1982 r. - Karta nauczyciela. Dz.U. 1982, nr 3, poz. 19 z późn. zm.

Ustawa z dnia 27 lipca 2005 r. - Prawo o szkolnictwie wyższym. Dz.U. 2005, nr 164, poz. 1365 $\mathrm{z}$ późn. zm.

Ustawa z dnia 6 czerwca 1997 r. - Kodeks karny. Dz.U. 1997, nr 88, poz. 553 z późn. zm. Wyrok Sąu Najwyższego z dnia 25 września 1985 r. IV PR 200/85, OSNC 1986/5/84.

Wyrok Sądu Najwyższego z dnia 8 października 1981 r. IV PR 301/81, OSNC 1982/2-3/43.

\section{Źródła internetowe}

Odpowiedzialność cywilna nauczycieli - zasady ogólne. http://www.oswiata.abc.com.pl/czytaj/-/ artykul/odpowiedzialnosc-cywilna-nauczycieli-zasady-ogolne.

Pismo Ministerstwa Edukacji Narodowej z dnia 9 maja 2017 r., 11846/2017, LEX nr 351099.

Rudnik J.: Odpowiedzialność cywilno-prawna i zadania nauczycieli zwiąane z bezpieczeństwem uczniów. http://www.oskko.edu.pl/wroclaw2013/materialy/odpowiedzialnosc_prawna_nauczy cieli.pdf.

Stownik języka polskiego PWN. https://sjp.pwn.pl/sjp/;2493511. 